\title{
CORPORATE GOVERNANCE AND VOLUNTARY DISCLOSURE PRACTICES IN CZECH REPUBLIC
}

\author{
Abdul Mansulu ${ }^{1}$ \\ ${ }^{1}$ Department of Accounting and Taxation, Faculty of Economics, Mendel University in Brno, Zemědělská 1, 61300 \\ Brno, Czech Republic
}

Link to this article: https://doi.org/10.11118/actaun.2021.012

Received: 10. 7. 2020, Accepted: 18. 1. 2021

To cite this article: MANSULU ABDUL. 2021. Corporate Governance and Voluntary Disclosure Practices in Czech Republic. Acta Universitatis Agriculturae et Silviculturae Mendelianae Brunensis, 69(1): 111-125.

\begin{abstract}
The decision to disclose enough information in annual reports is seen as an act of transparency. This study seeks to measure the extent of voluntary disclosure and to examine the relationship between corporate governance determinants and the level of voluntary disclosure. The study reports an average of 51.5\% as the level of voluntary disclosure. Four corporate governance variables are used as the basis for the regression analysis. The evidence shows a positive association between the level of voluntary disclosure and the proportion of independent directors, block holder and the proportion of the audit committee with only the proportion of audit committee to the board showing statistical significance. The board size has a negative association. The category of corporate governance information items as part of the total voluntary checklist is largely disclosed among Czech firms. The study contributes to the literature on voluntary disclosure in a transition economy. The findings prove useful to investors and financial statement preparers as the knowledge informs them to question and request more information from the firms which are open to the capital market.
\end{abstract}

Keywords: voluntary disclosure, corporate governance, blockholder, board size, audit committee

\section{INTRODUCTION}

The widespread collapse of firms across the world in recent times in cases like Enron and Lehman Brothers both in the USA, Pescanova in Spain, Amir -Mansour Aria in Iran, One. Tel in Australia, UT Bank in Ghana among others sent a message across to corporate stakeholders about the importance of corporate governance. The scandals were an obvious revelation of organizational inefficiencies, weaknesses and poor corporate governance (Al-Shammari and Al-Sultan, 2010). The obvious effects of poor corporate governance on the going concern of corporate entities bring the subject to the attention of professionals and academicians. Corporate governance reforms and code of best practices are established as a means to regain confidence in the financial markets to ensure market integrity, corporate accountability and transparency. A key approach of capital market dynamics which has received increased attention to subvert bad corporate governance and allow for corporate transparency is disclosure. Good corporate governance and the free choice of disclosure of accounting information contribute immensely in reducing the agency problem as management openness and accountability in doing business is represented (Al-Sartawi et al., 2016). Implementation of corporate governance principles and the free choice of disclosure minimize the systemic issues of corporate responsibility and accountability (Samaha et al., 2012) and reduces corporate financial risk (Albitar, 2015) which invariably as a supplement to financial and economic reforms may attract foreign direct investment (Al Janadi et al., 2016). Disclosure has gained this attention from researchers as suggested from empirical studies (Eng and Mak, 2003; Haniffa and Cooke, 2002; Chau and Gray, 2002). With 
the growing interest on the topic of voluntary disclosure, prior studies (Cheng and Courtenay, 2006; Meek et al., 1995) have been conducted to examine how voluntary disclosure is influenced by several corporate factors. Research attention in recent times have been devoted on the impact of corporate governance on voluntary disclosure.

Unlike the developed countries where several studies on the topic exist, the situation is different for the transitional economies. The focus has been on largely companies in US, UK and their counterpart in giant European countries but this study is narrowed on firms listed on the Prague Stock Exchange of the Czech Republic. One of the objectives is to identify the relationship between the level of voluntary disclosure of the listed firms in Czech Republic and the corporate governance items disclosed by them. To secure a strong capital market which is robust and efficient, a lot of factors come into play of which a sound corporate governance system cannot be abased. Therefore, encouraging the disclosure of accounting information based on free choice and adequate enough on corporate governance items attract a positive attention. A developing capital market like that of Czech Republic may robe in many gains from the investor community on the knowledge of providing a clear and consistent path to transparency when the regulatory regime enforces the need for openness of information to the corporate world. There are key contributions that the study obviously provides and this is the motivation for the study. The study is the first of its kind in the Czech Republic. It provides literature on voluntary disclosure study. It again adds to literature on the corporate governance determinants which influences the level of voluntary disclosure in Czech Republic. It is for this reason why the study seeks to examine the corporate governance attributes that influence voluntary disclosure and also measure the extent of voluntary disclosure. The study presents some contributions to the literature. The findings of the study will reveal how much the firms are concerned with making discretionary information available to users as part of their responsibility towards information disclosure. The Czech regulatory bodies responsible for financial reporting may have the responsibility to use the outcome to formulate guidelines, rules and regulation useful to strategise and make demands on full and fair disclosure from financial statement preparers. Since, stakeholder interest rest much on the information available to them, management of the company may use the findings to know and understand how much information they make available so as to improve on for the best interest of their companies. Lastly, other users like investors and creditors may have knowledge about the level of disclosure by firms which may help them ask questions and demand more from the companies.
There are two objectives developed for the study stated as follows:

1. To examine the level of voluntary disclosure by nonfinancial firms listed on the Prague Stock Exchange and

2. To identify the corporate governance attributes that determine the level of voluntary disclosure.

The other section of the paper is organized as follows. Section 2 discusses the literature review with a focus on hypotheses. Section 3 looks at the data collection and sample and the measurement of variables. Section 4 presents the results and discussion of the findings and the conclusion, limitations and recommendations are finalized in section 5 .

\section{Literature Review}

\section{Theories on Disclosure}

There are several differences in the nature and level of voluntary disclosure on corporate governance and other firm attributes in the same country and industry and across firms, countries and regions as well. This is dependent on the incentive for the disclosure. The incentive for the disclosure drives firms to either disclose nothing, few or adequate information. Owusu-Ansah (1998) has defined disclosure as the communication of economic information whether financial or nonfinancial quantitative or otherwise concerning a company's financial position and performance. Enormous studies have been conducted to know the determinant of disclosure at various scale and some theories have emerged which provide explanation to the discrepancy in the level of voluntary disclosure. For the purpose of this study only two of such theories are considered.

\section{Agency Theory}

Several research works on corporate governance disclosure have been drawn from the agency theoretical framework. The agency theory explains an agency problem which arises from the relationship that exist between two parties where one party (agent) works on behalf of the other party (principal). Shareholders and management relationship in a corporate setting is an epitome of the agency theory where managers have it as a duty to protect the interest of the shareholders but rather are noted to pursue a self-serving goal. Jensen and Meckling (1976) revealed that the resulting consequence which is conflict and tension may lead to an agency cost. Fama and Jensen (1983) suggested the need to tie managerial compensation to some selected performance indicators so that manager's earnings may increase as they increase the wealth of shareholders; as a means to reduce the agency cost. Alves et al. (2012) was of the view that this tension between shareholders and managers which result in agency cost can 
be decrease if companies resort to disclosure of voluminous voluntary information since disclosure is seen as an effort to show openness and to reduce information asymmetry. Watson et al. (2002) pointed out that the board's approval for disclosing more information is tied to the quality of the annual report. Barako et al. (2006) was of the view that the surest way to alleviate the agency conflict is the voluntary disclosure mechanism where sufficient and adequate additional (voluntary) information is provided which increases reliability in annual reports.

\section{Stakeholder Theory}

This theory was born out of the limitation of the agency theory where the center of management interest is the shareholders of the company at the neglect of other entities of the firm's environment. These entities include employees, creditors, bankers, general public, managers, government agencies. The totality of all these entities are called stakeholders who according to Freeman (1984) are individuals and groups whose actions affect or are affected by the operations and activities of a business. The stakeholder theory establishes the relationship that exist between the business behaviour and how it impacts the stakeholders. The relation is that the company exist for the stakeholders and on the other side the company's survival is dependent on the support of the stakeholders. To allow for informed decision to be taken by the entities, the stakeholders have it as an expectation to receive adequate information from the company. An all-purpose financial information brings satisfaction to all stakeholders since it allows individuals and groups to choose and pick information useful and relevant for their consumption. Ofoegbu et al. (2018) pointed that the surest way for a long lasting relationship to exist between the firm and the entities in the firm's environment is for the former to constantly provide adequate information.

\section{Corporate Governance and Voluntary Disclosure}

Corporate governance is a key contribution to corporate growth since it gives direction and facilitates operational success. Several definitions have been given for corporate governance but OECD (2004) defines it as an expression of relationship between relevant stakeholders of the company. It is an interaction that happens among the business actors both internally and externally. Internal interaction is noted among management, board and the shareholders whereas the external relationship is noted among the outside entities who have the corporate interest. Corporate governance has become an ingredient for corporate success since its practice reduces information asymmetry, lowers the cost of capital and allows for greater accountability and transparency. The corporate governance code of the Czech Republic is instituted like all other forms of corporate governance codes to ensure a uniform but flexible way by which corporate firms are to control and direct their activities. The Czech corporate governance code is in perfect harmony with the principles of good corporate governance (OECD, 2004). Rentsch and Vajdik (2012) indicated a formation of corporate governance code by the Czech Securities Commission (CSC) premised on OECD principles (2004) for their companies. Noted in their submission are the fundamental sources following codes and acts which constituted the Corporate Governance Regulation in the Czech Republic (CGRCR). In the Czech Republic, corporate governance covers issues such as the right and equitable treatment of shareholders, corporate control, the responsibility of the board and disclosure and transparency (OECD, 2014). These issues are picked and discussed constantly to shape the dynamic environment for which these principles are instituted.

In order to subvert bad corporate governance and allow for corporate transparency, disclosure has become the focal approach of most firms which aims to mitigate the inherent threat a business may face for having no information which may aid economic judgment. Disclosure has gained this attention from researchers as suggested from empirical studies (Eng and Mak, 2003; Haniffa and Cooke, 2002; Chau and Gray, 2002). To look into it, several empirical studies exist on disclosure policy and corporate topics like corporate governance (Al-Janadi et al., 2013); foreign share ownership (Bokpin and Issahaq, 2009); the board of directors' independence (Liu et al., 2016; Cheng and Courtenay, 2006); and complexity of the market, the relevance of intangible and investor management (Boesso and Kumar, 2007) which have all been identified as determinants of the extent of voluntary disclosure. Alves et al. (2012) examined the relationship between corporate attributes, corporate governance and voluntary disclosure and concluded that the board compensation and the size of shareholders have an association with the level of voluntary disclosure. More so, a high number of directors and independent directors on the board and low proportion of director's ownership in Malaysian firms allowed for increased voluntary disclosure on financial information (Htay, 2012). Chen and Jaggi (2000) performed an extensive work on the association between independent nonexecutive directors, family control and financial disclosures in Hong Kong. The findings revealed that the ratio of independent directors to the total number of directors on corporate boards increases as the comprehensiveness of financial disclosure increases and in comparison established that family controlled firms unlike non-family controlled businesses have a weaker association with the proportion of the independent directors to the total 
number of directors. In support of the worthwhile studies, openness to the market through the provision of full and fair disclosure can give firms some economic gains by attracting capital providers.

\section{Development of Hypotheses}

Enormous literature exists in this area with umpteen argument explaining why some firms by choice hastily disclose comprehensive information than others. Determinants such as board size, audit quality, frequency of meeting, the audit committee, the structure of ownership, the existence of dominant personality, independent directors among others have been analyzed as the factors that determine the extent of voluntary disclosure (Barros et al., 2013).

\section{Board Size and Voluntary Disclosure}

Considering the growing intricacies that have evolved in today's business, firms need input sufficiently rich to make it have control over their environment (both internal and external). This development makes it very imperative to have directors who represent different groups of stakeholders (Bouaziz, 2014). The quality of long-term strategy decisions may be dependent on the composition of the board. A firm's board consists of professionals with depth of knowledge, distinguished skill set, expertise and experiences on strategic issues relevant to inform better judgement. Arguments exist in literature based on the size of the board. Jensen (1993) suggested a small board size if a firm wants to be efficient since they are able to focus and deal with issues to the very depth. Cheng and Courtenay (2006) also hinted about the negative effect on board performance in cases where the board size is large. A larger board decrease information asymmetry among insiders and outsiders and positively influence the level of voluntary disclosure within the firm (Akhtaruddin et al., 2009). Yermack (1996) expressed the opinion that a large board size leads to poor communication and interaction among directors. Allegrini and Greco (2013) contested that based on the agency theory, larger board size matters in monitoring management behavior. The right number of a corporate board is influenced by some factors notably diversity, independence, functions, skills, talents, abilities, areas of expertise, representational requirement and regulatory requirement. Empirically, several studies conducted concluded on a positive association between board size and voluntary disclosure (Samaha et al., 2012; Akhtaruddin et al., 2009). However, Gyamerah and Agyei (2016) found no such relationship. It is therefore hypothesized that,

H1: The size of the board of directors has a positive relationship with the level of voluntary disclosure.

\section{Independent Directors and Voluntary Disclosure}

Monitoring remains one key important element in corporate governance mechanism discussion; reason assigned to the agency problem (Jensen and Meckling, 1976). Independent directors have responsibility to protect the interest of shareholders and other stakeholders against actions that may be beneficial to managers who often could have a self-serving interest. This makes the ratio of the independent directors on the board an important variable. An inclusion of directors who are external to the direct operation of the firm act as an internal control mechanism aimed at hindering shareholder's expropriation (Fama, 1980). Empirical research consistently shows that proportionately larger independent non-executive directors on the board reduce the possibility of fraudulent information (Mak and Li, 2001; Chen and Jaggi, 2000). Evidence that the ratio of independent directors to the size of the board has a positive relationship with voluntary disclosure in annual reports is supported regardless of country differences in prior studies (Al-Maskati and Hamdan (2017) in Bahrain; Cornier et al. (2010) in Canada; Akhtaruddin et al. (2009) in Malaysia; Patelli and Prencipe (2007) in Italy and Cheng and Courtenay (2006) in Singapore). Gyamerah and Agyei (2016) found no evidence for voluntary disclosure and independent directors. Al-Shammari and Al-Sultan (2010) found negative evidence in Kuwait. The variable is measured as the ratio of independent directors to the total membership of the board.

H2: The proportion of independent directors (PID) is positively related to the level of voluntary disclosure.

\section{Audit Committee and Voluntary Disclosure}

Ho and Wong (2001) opined that voluntary disclosure is also influenced by the presence of an audit committee The audit committee of a firm has the task to consider matters regarding the assessment of the effectiveness of the company internal inspections and procedures relating to the financial statement preparation and process of mandatory audit. Rouf (2011) emphasized the attracted confidence, accuracy and error-free nature of financial statements when there is a presence of an audit committee on the board. In the Czech Republic, a supervisory board is responsible for reviewing the financial statement and a proposal for the distribution of profits. For its listed companies, an audit committee is responsible for supervising the audit procedures within the company purposely aimed to enhance the transparency and disclosure of the statement. The audit committee serves as a force used to reduce agency costs and to improve disclosure (Forker, 1992). Findings of the audit committee on voluntary disclosure are variant to countries as Al-Shammari and Al-Sultan (2010) found positive evidence in Kuwait, Elfeky (2017) 
and Akhtaruddin et al. (2009) found no such evidence. The proportion of the audit committee is measured as the ratio of the audit committee members to the total membership of the board.

H3: A higher proportion of audit committee (PAC) members to the total members on board is positively related to the level of voluntary disclosure.

\section{Block Holder and Voluntary Disclosure}

In the seminal work of Jensen and Meckling (1976), it came to light that in cases where there are diffused ownership, companies disclose more information based on the agency theory. Ownership structure may be presented as wholly owned by a single entity or fragmented entities with varying shares. Block holders basically are those shareholder group(s) with a significant number of shares that is 5\% or more (Eng and Mak, 2003). Institutional investors, the government and individuals happen to be these block holders. Elfeky (2017) indicated that there is likely sufficient disclosure in cases where companies have dispersed ownership with a significant stake. It is argued that the level of interest (proxy as the percentage owned) informs the level of information expected to be disclosure hence a positive association. Eng and Mak (2003) and Haniffa and Cooke (2002) found no relationship between the two though. The measure of the variable is the cumulative proportion of equity shares owned by shareholders with shares that exceed 5\%. As supported by several studies in favor of a positive relation between block holder and the level of voluntary disclosure, the hypothesis is stated as:

H4: Block holder has a positive association with the level of voluntary disclosure.

\section{MATERIALS AND METHODS}

\section{Sample and Data Collection}

The study focuses on listed firms but limited to non-financial firms on the Prague Stock Exchange covering the period 2011 to 2017. Out of the 17 listed firms as of December, 2017, 10 firms are chosen for the study and the data is sourced from the Orbit database and website of the firms. Key data is extracted only from the annual reports of the selected firms. Financial firms listed or nonfinancial firms listed without accessible data are excluded from the study, therefore, reducing the sample size. In all, 65 firm's year dataset is used.

\section{Voluntary Disclosure Score}

A self-constructed disclosure index is developed to measure the total score of voluntary disclosure (VDScore) and six sub-indices. A disclosure checklist from empirical studies are adopted as the basis to arrive at the overall disclosure index and sub-indices (Al-Maskati and Hamdan, 2017; Al-Shammari and Al-Sultan, 2010; Eng and Mak,
2003; Chau and Gray, 2002 and Meek et al., 1995). In all, a total of 61 voluntary items are developed and placed under 6 categories. The categories are corporate governance information (CORGOV), corporate environment information (CORENV), financial information (FIN), forecast information (FOCST), corporate social responsibility information (CSR) and employee information (EPLOY). The items are adequate to cover relevant areas of corporate governance matters. Without any specific user in mind, all items disclosed are rated with equal importance notwithstanding the fact that there are some substantial differences in the value of each item. A value of 1 is assigned if an item is disclosed, 0 for otherwise and NA if non-applicable. This is the unweighted approach of disclosure scoring. The VDScore for a firm is arrived at by dividing the number of items actually disclosed by the maximum expected disclosure for each firm.

\section{Model Specification}

To examine the association between the dependent and the predictive and control variables, a linear multiple regression model is constructed. The estimate is given as:

Model 1

$\operatorname{VDSCORE}_{i t}=\alpha+\beta_{1}$ SSIZE $_{i t}+\beta_{2} P I D_{i t}+\beta_{3} B H O L D_{i t}+$

$+\beta_{4} P A C_{i t}+\beta_{5} L O G F S_{i t}+\beta_{6} L E V_{i t}+\beta_{7} R O A_{i t}+\beta_{8} A I P_{i t}+\varepsilon_{i t}$,

where:

VDSCORE..voluntary disclosure index for each sample firm,

BSIZE.........board size,

PID ..............proportion of independent directors,

BHOLD .....blockholder Ownership,

PAC............proportion of audit committee,

LOGFS........log of firm size,

$L E V$............leverage,

$R O A$............return on asset,

ROE.............return on equity,

AIP .............asset in place,

a...................constant,

$\beta_{1}-\beta_{8} \ldots \ldots . . . . .$. the estimated coefficient of the predictive and control variables,

$i$................... firm,

t.................time and

$\varepsilon$.................the error term.

\section{Variable Measurement}

The predictive variables selected are board size, proportion of independent directors, blockholder and the audit committee to the board and the data for the analysis are all extracted from the annual report of the companies. The unweighted measurement approach of disclosing is applied for these variables. A value of 1 is assigned if an item is disclosed, 0 if not disclosed and NA for not applicable. Beside the corporate governance 
variables, four firms' characteristics are used as control variables which are considered to influence the level of voluntary disclosure. The variables used are firm size, asset-in-place, profitability and leverage. These variables are used since they form a general part in most corporate attribute discussion and can be considered to influence the extent of voluntary disclosure. The measures of all the variables are given in Tab. I.

\section{RESULTS AND DISCUSSION}

\section{Descriptive Statistics of the Variables}

Tab. II presents the descriptive statistics of the study. It reports on the mean, standard deviation, minimum and maximum values. The variables are categorized into panels (A-D). Panel A shows the level of voluntary disclosure (VDScore) which is $51.5 \%$. The range of the mean values for the level of voluntary disclosure are 0.77 and 0.25 for the maximum and minimum values respectively. The values for the minimum and the maximum voluntary disclosure score indicates clearly a wide variation in the voluntary practice among both countries.

Panel B also reports on the descriptive statistics of the six sub-indices. The results of the level of disclosure on the sub-indices in a descending order are CORGOV (0.914), CSR (0.731), CORENV (0.635), FIN (0.385), EPLOY (0.204) and lastly FOCST (0.089). The result from the annual reports of the listed firms in Czech Republic indicates that corporate governance information (CORGOV) category has the highest level of disclosure (0.914). This is so since the corporate governance details are of much

I: Measurement of variables

\begin{tabular}{|c|c|c|c|}
\hline Variable Name & $\begin{array}{c}\text { Abbreviation } \\
\text { of variables }\end{array}$ & Variable description & Exp. Sign \\
\hline \multicolumn{4}{|c|}{ Dependent } \\
\hline Overall voluntary disclosure & VDScore & $\begin{array}{l}\text { Percentage of overall applicable disclosure/expected } \\
\text { disclosure }\end{array}$ & \\
\hline $\begin{array}{l}\text { Corporate governance disclosure } \\
\text { sub-index }\end{array}$ & CORGOV & $\begin{array}{l}\text { Percentage of applicable disclosure index for the CORGOV } \\
\text { sub-index }\end{array}$ & \\
\hline $\begin{array}{l}\text { Corporate environment } \\
\text { disclosure sub-index }\end{array}$ & CORENV & $\begin{array}{l}\text { Percentage of applicable disclosure index for the CORENV } \\
\text { sub-index }\end{array}$ & \\
\hline Financial information sub-index & FIN & $\begin{array}{l}\text { Percentage of applicable disclosure index for the FIN } \\
\text { sub-index }\end{array}$ & \\
\hline Forecast information sub-index & FOCST & $\begin{array}{l}\text { Percentage of applicable disclosure index for the FOCST } \\
\text { sub-index }\end{array}$ & \\
\hline $\begin{array}{l}\text { Corporate social responsibility } \\
\text { sub-index }\end{array}$ & CSR & $\begin{array}{l}\text { Percentage of applicable disclosure index for the CSR } \\
\text { sub-index }\end{array}$ & \\
\hline Employee information sub-index & EPLOY & $\begin{array}{l}\text { Percentage of applicable disclosure index for the EPLOY } \\
\text { sub-index }\end{array}$ & \\
\hline \multicolumn{4}{|c|}{ Explanatory } \\
\hline Board Size & BSIZE & The total membership of directors on the board & + \\
\hline $\begin{array}{l}\text { Proportion of Ind. Executive } \\
\text { directors }\end{array}$ & PID & $\begin{array}{l}\text { The percentage of independent directors to the total size } \\
\text { of the board }\end{array}$ & + \\
\hline Block holder Ownership & BHOLD & $\begin{array}{l}\text { The proportion of aggregate ordinary shares owned by } \\
\text { substantial shareholders (with shares of 5\% and more) }\end{array}$ & + \\
\hline $\begin{array}{l}\text { Proportion for audit committee } \\
\text { members }\end{array}$ & AUDCOM & $\begin{array}{l}\text { The percentage of the audit committee to total board } \\
\text { membership }\end{array}$ & + \\
\hline \multicolumn{4}{|c|}{ Control } \\
\hline Return on Asset & $\mathrm{ROA}$ & $\begin{array}{l}\text { The earnings after tax and interest expressed as a ratio } \\
\text { on total asset }\end{array}$ & + \\
\hline Return on Equity & $\mathrm{ROE}$ & $\begin{array}{l}\text { The earnings after tax and interest expressed as a ratio } \\
\text { on shareholders' equity }\end{array}$ & + \\
\hline Leverage & LEV & The ratio of long-term debt to the book value of equity & + \\
\hline Firms Size & LOGFS & Log of Total non-current asset & + \\
\hline Asset in place & AIP & Ratio of tangible non-current asset to non-current asset & + \\
\hline
\end{tabular}

Source: Authors own construct 
II: Descriptive statistics

\begin{tabular}{|c|c|c|c|c|}
\hline Variables & Mean & Std. Dev & Min & Max \\
\hline \multicolumn{5}{|c|}{ Panel A: Dependent (main index) } \\
\hline VDSCORE & 0.515 & 0.163 & 0.254 & 0.77 \\
\hline \multicolumn{5}{|c|}{ Panel B: Dependent (Sub-indices) } \\
\hline CORGOV & 0.914 & 0.138 & 0.555 & 1 \\
\hline CORENV & 0.635 & 0.206 & 0.235 & 1 \\
\hline FIN & 0.385 & 0.186 & 0.188 & 0.812 \\
\hline FOCST & 0.089 & 0.218 & 0 & 0.8 \\
\hline CSR & 0.731 & 0.427 & 0 & 1 \\
\hline EPLOY & 0.204 & 0.243 & 0 & 0.714 \\
\hline \multicolumn{5}{|c|}{ Panel C: Predictive } \\
\hline BDSIZE & 4.461 & 1.668 & 2 & 7 \\
\hline PID & 0.011 & 0.042 & 0 & 0.2 \\
\hline BHOLD & 0.749 & 0.145 & 0.51 & 1 \\
\hline AUDCOM & 0.645 & 0.359 & 0 & 1 \\
\hline \multicolumn{5}{|c|}{ Panel D: Control } \\
\hline LOGFS & 9.61 & 1.141 & 7.918 & 11.797 \\
\hline LEV & 0.199 & 0.404 & 0 & 2.427 \\
\hline ROA & 0.064 & 0.069 & -0.195 & 0.233 \\
\hline ROE & 0.102 & 0.126 & -0.307 & 0.395 \\
\hline AIP & 0.688 & 0.276 & 0.0002 & 1 \\
\hline
\end{tabular}

Source: Stata results

importance to investors. It is followed by CSR which is concerned with broad aspect of user groups. The FOCST came on the bottom due to the uncertainties and the non-predictability that the future presents and such uncertainties limits information disclosure. The first three sub-indices show a mean disclosure above the overall mean but all the sub-indices are widely dispersed around their mean. A clear indication that for each category there are some firms disclosing very high on them and others practically disclose nothing at all as shown in Tab. II. This may be likely due to the importance attached to that category and the benefit derived from those who have interest in such disclosure. Firms in developed countries are noted to disclose more to appeal to stakeholders on openness. Increased disclosure made by a firm gives more credence and endorsement to it which is more of a rewarding idea.

Panel $C$ shows the results of the predictive variables. The average board size for the study is 4.46 with the minimum and maximum board size range from 2 to 7 . Czech Republic uses the twotier approach of board structure (a structure with two separate boards - but the study focus is on the management board). The average of the PID is 0.01. Quite an insignificant value is recorded as PID for the Czech firms because almost all the board members are practically employees of the firms. For blockholder ownership, an average of 0.75 is reported. The outcome indicates that ownership of the firms are predominantly not in the hands of a few but are widely dispersed. The last of the predictive variable which is PAC revealed a mean of 0.65. It is explained that for every 3 directors, there is a representation of 2 audit committee members for the listed firms in Czech Republic.

Panel D in Tab. II also reveals the mean result of the control variables as 0.06, 0.20, and 0.69 for ROA, LEV and AIP respectively for the Czech firms. The report indicates that the sampled firms are profitable and also have a capital structure where more equity is used than debt (20\% leverage). Also for every $1 \mathrm{Czk}$ of an asset, $0.69 \mathrm{Czk}$ is invested into a non-current asset for Czech firms. The last variable which is the firm size (LOGFS) reports an average of 9.610 .

\section{Univariate Analysis}

Tab. III shows the relationship that exists among the variables. It reports that firms that are large in size in Czech Republic and have larger board size provide a higher level of voluntary disclosure on corporate governance variables $(r=0.76)$. The lowest correlation is between the size of the 
III: Pearson correlation coefficient

\begin{tabular}{|c|c|c|c|c|c|c|c|c|c|}
\hline Variables & VDSCORE & BDSIZE & PID & BHOLD & PAC & LOGFS & LEV & ROA & AIP \\
\hline BDSIZE & 0.5299 & 1 & & & & & & & \\
\hline PID & 0.1007 & 0.2091 & 1 & & & & & & \\
\hline BHOLD & 0.1862 & 0.0878 & -0.199 & 1 & & & & & \\
\hline PAC & 0.3888 & -0.08 & -0.246 & 0.1137 & 1 & & & & \\
\hline LOGFS & 0.7075 & 0.7672 & 0.0896 & 0.2254 & 0.0923 & 1 & & & \\
\hline LEV & 0.3209 & 0.2712 & -0.046 & 0.0828 & 0.1338 & 0.4276 & 1 & & \\
\hline ROA & -0.083 & -0.1852 & -0.077 & -0.2573 & 0.0567 & 0.0238 & -0.053 & 1 & \\
\hline AIP & 0.1087 & 0.0702 & 0.1204 & -0.1811 & 0.0655 & -0.1275 & 0.1622 & -0.261 & 1 \\
\hline
\end{tabular}

Source: Stata results

firm and the return on asset $(r=0.023)$. Tab. III indicates correlation values which are less than $80 \%$ indicating free correlation risk. Cooper and Schindler (2008) indicated that a problem of multicollinearity occurs when the correlation value in a correlation matrix exceeds the critical point of $80 \%$ which is not the case in this study.

\section{Multiple Regression Analysis}

Tab. IV provides the result of the multiple regression analysis of the study. An OLS regression is employed to examine the relationship between the level of voluntary disclosure and the predictive variables. Elfeky (2017), Rouf (2011), Akhtaruddin et al. (2009) and Wallace and Naser (1995), all used multiple regression as part of the analysis in similar studies. The result shows the relationship between the overall extent of voluntary disclosure of the corporate governance items for both explanatory and the control variables. Tab. IV displays the coefficients, $\mathrm{p}$-value, F-statistics, $\mathrm{R}^{2}$, adjusted $\mathrm{R}^{2}$ and finally the observation. The extent of voluntary disclosure is 0.65 explain by the variations in the totality of the independence variables use $\left(\mathrm{R}^{2}=0.65\right.$ and Adjusted $R^{2}=0.60$ ). The value of F-statistics is 13.31 at significance level $(p<0.01)$ for 65 recorded observations.

For the explanatory variables, the size of the board has a negative insignificant relationship with the level of voluntary disclosure. The hypothesis receives support which is consistent with prior studies (Elfeky, 2017; Gyamerah and Agyei, 2016). The positive relationship exists for Czech firms likely due to the adopted board structure. The twotier approach which is adopted separates the board into two categories of which one is the management board. The management board is a small size board with dominant management present on the board. The result explains that voluntary disclosure increases with small board size.

Tab. IV reports a positive association between voluntary disclosure and PID. The hypothesis is consistent with Czech firms. The coefficient of Czech Republic for PID ( $\beta=0.398)$ indicates that if the PID increases by 1 unit, the voluntary disclosure increases by 0.398 . This result shows that voluntary disclosure increases with the increased presence of external directors. Eng and Mak (2003) opined that this truly increases the board's independence.

The third hypothesis for the study stated a positive relationship between blockholder ownership and voluntary disclosure which is confirmed by the study ( $\beta=0.021$ ). Block holder ownership for the study is institutional ownership. These are made up of large institutions and well-established firms with people with the know-how to demand transparency and sufficient disclosure to ensure their interest is catered for. The result is consistent with prior studies (Mansulu and Anarfi, 2019). The results show that disclosure increases with greater institutional ownership. The increase in the level of disclosure for institutional investors is justified by the heterogeneity of the investors where varying information is needed to be disclosed to serve all interest and also reduce the agency problem through the sufficient disclosure.

The last of the predictive variables is hypothesized that the larger the ratio of the audit committee to the board of directors, the larger the level of voluntary disclosure. This hypothesis is supported $(\beta=0.154, p>0.01)$. The result is consistent with prior studies (Al-Shammari and Al-Sultan, 2010; Hannifa and Cooke, 2008). The result indicates that the increased presence of the audit committee on the board increases voluntary disclosure. The larger the audit committee members who have garnished enough accounting experience, the more they demand transparency and sufficient disclosure from managers.

There are six sub-indices that are the constituent of the main voluntary disclosure index. Showing in Tab. IV also are the results of the six-indices in relation to the predictive and control variables. These sub-indices are estimated to assess whether the relationship between the sub-indices and the independent variables differ from the overall voluntary disclosure. For instance, Tab. IV shows a positive relationship between audit committee 
IV: Multiple regression for the total voluntary disclosure index and sub-indices

\begin{tabular}{|c|c|c|c|c|c|c|c|}
\hline \multirow{2}{*}{$\frac{\text { Variables }}{\text { Predictive }}$} & \multicolumn{7}{|c|}{ Dependent Variables } \\
\hline & Model 1 & CORGOV & CORENV & FIN & FOCST & CSR & EPLOY \\
\hline \multirow{2}{*}{ BDSIZE } & -0.005 & $0.037^{* *}$ & -0.033 & -0.022 & 0.028 & $0.147^{* * *}$ & 0.016 \\
\hline & $(-0.37)$ & $(-2.22)$ & $(-1.61)$ & $(-1.31)$ & $(1.12)$ & $(4.18)$ & $(0.74)$ \\
\hline \multirow{2}{*}{ PID } & 0.398 & 0.107 & $1.158^{* *}$ & 0.393 & 0.317 & $-2.03 * *$ & $-1.586^{* * *}$ \\
\hline & $(-1.21)$ & $(-0.32)$ & $(-2.33)$ & $(0.95)$ & $(0.53)$ & $(-2.39)$ & $(-2.99)$ \\
\hline \multirow{2}{*}{ BHOLD } & 0.021 & -0.041 & -0.003 & -0.004 & 0.345 & 0.351 & $-0.292^{*}$ \\
\hline & $(-0.20)$ & $(-0.40)$ & $(-0.03)$ & $(-0.03)$ & $(1.86)$ & $(1.35)$ & $(-1.80)$ \\
\hline \multirow{2}{*}{ AUDCOM } & $0.154^{* * *}$ & $0.142^{* * *}$ & 0.139 & 0.063 & $0.245^{* * *}$ & $0.483^{* * *}$ & 0.068 \\
\hline & $(-4.03)$ & $(-3.68)$ & $(-2.41)$ & $(1.31)$ & $(3.50)$ & $(4.92)$ & $(1.12)$ \\
\hline \multicolumn{8}{|c|}{ Control } \\
\hline \multirow{2}{*}{ LOGFSIZE } & $0.107^{* * *}$ & 0.032 & $0.151^{* * *}$ & $0.138^{* * *}$ & $-0.122^{* * *}$ & 0.045 & $0.126^{* * *}$ \\
\hline & $(-4.93)$ & $(-1.49)$ & $(-4.62)$ & $(5.05)$ & $(-3.08)$ & $(0.82)$ & $(3.62)$ \\
\hline \multirow{2}{*}{ LEV } & -0.024 & -0.014 & -0.0753 & -0.014 & -0.003 & -0.016 & -0.001 \\
\hline & $(-0.65)$ & $(-0.38)$ & $(-1.36)$ & $(-0.30)$ & $(-0.05)$ & $(-0.18)$ & $(-0.01)$ \\
\hline \multirow{2}{*}{ ROA } & -0.181 & -0.321 & -0.0417 & 0.183 & -0.0134 & 0.046 & $-1.376^{* * *}$ \\
\hline & $(-0.85)$ & $(-1.49)$ & $(-1.30)$ & $(0.68)$ & $(-0.34)$ & $(0.08)$ & $(-4.00)$ \\
\hline \multirow{2}{*}{ AIP } & $0.098^{* *}$ & 0.005 & $0.146^{*}$ & $0.256^{* * *}$ & -0.071 & 0.069 & 0.048 \\
\hline & $(-1.85)$ & $(-0.11)$ & $(-1.84)$ & $(3.84)$ & $(-0.74)$ & $(0.051)$ & $(0.57)$ \\
\hline \multirow{2}{*}{ _CONS } & -0.663 & 0.419 & -0.083 & -1.072 & 0.784 & -0.097 & -0.839 \\
\hline & $(-3.85)$ & $(-2.41)$ & $(-3.20)$ & $(-4.93)$ & $(2.48)$ & $(-2.19)$ & $(-3.03)$ \\
\hline F-Statistics & 13.31 & 7.28 & 7.37 & 9.77 & 3.81 & 14.08 & 10.51 \\
\hline F-Sign. & 0.00 & 0.00 & 0.00 & 0.00 & 0.00 & 0.00 & 0.00 \\
\hline $\mathrm{R}^{2}$ & 0.6553 & 0.509 & 0.513 & 0.582 & 0.352 & 0.668 & 0.6 \\
\hline Adjusted $\mathrm{R}^{2}$ & 0.6061 & 0.44 & 0.44 & 0.522 & 0.26 & 0.62 & 0.543 \\
\hline Observations & 65 & 65 & 65 & 65 & 65 & 65 & 65 \\
\hline
\end{tabular}

Note: Coefficient for each variable is shown, with $t$-statistics in parentheses

${ }^{*} \mathrm{p}<0.10$, two-tailed; ${ }^{* *} \mathrm{p}<0.05$, two-tailed; ${ }^{* * *} \mathrm{p}<0.01$, two-tailed

Source: Stata results

and all the six sub-indices as well as the overall disclosure in the case of Czech Republic. Similarly, the PID shows a positive association with all the subindices (except for CSR and EPLOY). The coefficient of the board size (except for CORENV and FIN) are positively related with the six-sub-indices whereas all the sub-indices (except for FOCST and CSR) are negatively related with blockholder ownership. Generally, the findings presented in Tab. IV is largely consistent with the outcome for the overall disclosure as impacted by the corporate governance variables. The reason for the differences in the coefficient of the sub-indices is the attached importance that the firms may give to the various categories of the corporate governance voluntary disclosure items.

In the case of the control variables, the regression result is also analyzed. The size of the firm and the asset in place have a positive association with voluntary disclosure but rejected the null hypothesis at the significance level $(p>0.05)$. On the other hand, the return on asset and leverage both have a negative insignificant relationship with the level of voluntary disclosure.

\section{Robustness Check}

Further analysis is examined on the robustness of the findings. Robustness is conducted to examine the behaviour of the coefficient of key regressors when there is a change in the regression model by adding, modifying or eliminating regressors. Three alternative models are created and named as models A, B and C. Two profitability measures are employed namely return on asset (ROA) and return on equity (ROE). Model A is treated the same as the main model but replaces the ROA in the main model with ROE. Tab. V shows that the result is consistent with the one obtained using the main model. The 
V: Sensitivity analyses of the corporate governance disclosure variables

\begin{tabular}{|c|c|c|c|}
\hline Variable & Model A & Model B & Model C \\
\hline \multicolumn{4}{|c|}{ Predictive } \\
\hline \multirow{2}{*}{ BDSIZE } & -0.005 & -0.005 & $0.027^{*}$ \\
\hline & $(-0.38)$ & $(-0.42)$ & $(1.86)$ \\
\hline \multirow{2}{*}{ PID } & 0.38 & 0.378 & -0.273 \\
\hline & $(-1.16)$ & $(-1.14)$ & $(-0.76)$ \\
\hline \multirow{2}{*}{ BHOLD } & 0.031 & 0.024 & 0.059 \\
\hline & $(-0.33)$ & $(-0.24)$ & $(0.54)$ \\
\hline \multirow{2}{*}{ AUDCOM } & $0.151^{* * *}$ & $0.151^{* * *}$ & $0.190^{* * *}$ \\
\hline & $(-3.97)$ & $(-3.94)$ & $(4.58)$ \\
\hline \multicolumn{4}{|c|}{ Control } \\
\hline \multirow{2}{*}{ LOGFSIZE } & $0.110^{* * *}$ & $0.111^{* * *}$ & $0.062^{* *}$ \\
\hline & $(-5.04)$ & $(-4.99)$ & $(2.62)$ \\
\hline \multirow{2}{*}{ LEV } & -0.024 & -0.024 & -0.02 \\
\hline & $(-0.65)$ & $(-0.65)$ & $(-0.52)$ \\
\hline \multirow{2}{*}{ ROA } & & -0.054 & -0.336 \\
\hline & & $(-0.21)$ & $(-1.45)$ \\
\hline \multirow{2}{*}{ ROE } & -0.134 & -0.117 & \\
\hline & $(-1.19)$ & $(-0.84)$ & \\
\hline \multirow{2}{*}{ AIP } & $0.094^{* *}$ & $0.093^{* *}$ & 0.075 \\
\hline & $(-1.79)$ & $(-1.74)$ & $(1.32)$ \\
\hline \multirow{2}{*}{ _CONS } & -0.69 & -0.685 & -0.418 \\
\hline & $(-4.02)$ & $(-3.93)$ & $(-2.23)$ \\
\hline F-Statistics & 13.55 & 11.85 & 11.9 \\
\hline F-Sign. & 0.000 & 0.000 & 0.000 \\
\hline $\mathrm{R}^{2}$ & 0.6594 & 0.6597 & 0.629 \\
\hline Adjusted $\mathrm{R}^{2}$ & 0.6108 & 0.604 & 0.577 \\
\hline Observations & 65 & 65 & 65 \\
\hline
\end{tabular}

Note: Coefficient for each variable is shown, with $t$-statistics in parentheses

${ }^{*} \mathrm{p}<0.10$, two-tailed; ${ }^{* *} \mathrm{p}<0.05$, two-tailed; ${ }^{* * *} \mathrm{p}<0.01$, two-tailed

Source: Stata results

study uses both profitability measures, namely ROA and ROE to generate model $\mathrm{B}$. This result is also consistent with Model A.

It is explained that all the 61 voluntary items constituting the VDSCORE have equal weight, but there are differences in the number of items across the six sub-indices resulting in varying weight assigned to each sub-index: CORGOV 11 (18.03\%); COREVN 17 (27.87\%); FIN 16 (26.23\%); FOCST 5 (8.2\%); CSR 4 (6.55\%) and EPLOY 8 (13.11\%).
Model $\mathrm{C}$ is an alternate index in which equal weight of $(16.66 \%)$ is assigned to each of the six sub-indices in order to know whether the results may be unchanged regardless of the weighting of the subindices. The outcome as shown in Tab. V indicates largely consistent results with the non-weighted total index. Generally, it can be said that all the three models are largely consistent with model 1 and therefore reinforces the understanding that the study results are robust.

\section{CONCLUSION}

Studies on corporate governance determinants in relation to voluntary disclosure in recent years have become a key area of concern because of how it affects a firm's outlook. The study examines those factors that impact voluntary disclosure with specific reference to corporate governance 
attributes. It again examines whether blockholder, the size of the board, the percentage of the audit committee to the board and independent directors to the board can explain the variation in the extent of voluntary disclosure compliance. The study also controls for the impact of firm attributes notably firm size, leverage, asset in place and return on equity.

The study findings reported a mean corporate governance voluntary disclosure of 51.5\%. The outcome is higher compared to studies conducted in most emerging countries like Elfeky (2017) in Egypt (34\%); Alfraih and Almutawa (2017) in Kuwait (23\%) but lower to Akhtaruddin et al. (2009) in Malaysia (53\%). The results of the study have several implications. The study result indicates that lesser board size is associated with more voluntary disclosures. The percentage of the independent directors to the total members on the board is proven to be associated with the level of voluntary disclosure. This implies that the increase presence of the independent directors increases the corporate transparency and disclosure. The regulatory authorities with this idea can set out guidelines aimed to demand from the management board through the independent director's adequate disclosure of information. The finding for blockholder supports the hypothesis. The result show that disclosure increases with greater institutional ownership. The increase in the level of disclosure for institutional investors is justified by the heterogeneity of the investors where varying information is needed to be disclosed to serve all interest and also reduce the agency problem through the sufficient disclosure. Lastly the percentage of audit committee to the total members on the board is consistent with the hypothesis. The result indicates that the increased presence of the audit committee on the board increases voluntary disclosure. With the grouping of the voluntary disclosure items checklist, corporate governance information items are identified to be more disclosed by Czech firms followed by corporate social responsibility items and the sixth and last category is the forecast information. It is upheld that sufficient disclosure is not evidence of transparency, but the provision of adequate information based on choice coupled with the effective practice of corporate governance demonstrate reporting enforcement and firm's commitment. Transparency and sufficient disclosure inspire investor confidence and draw commitment from the part of capital providers to allocate their resources as such. With the expectation of growth for the Czech Republic within the EU, the financial and economic reform and strategic positioning to attract foreign direct investment makes it prudent for enough disclosure, transparency and corporate accountability. Therefore, critical attention to corporate governance and the sufficient disclosure of information in the financial reports of their quoted firms enhances the firm's reputation and readiness for such economic takeoff.

It is for this reason why the study seeks to examine the corporate governance attributes that influence voluntary disclosure and also measure the extent of voluntary disclosure. The study presents some contributions to the literature. The findings of the study will reveal how much the firms are concerned with making discretionary information available to users as part of their responsibility towards information disclosure. The Czech regulatory bodies responsible for financial reporting may have the responsibility to use to outcome to formulate guidelines, rules and regulation useful to strategies and make demands on full and fair disclosure from financial statement preparers. Since, stakeholder interest rest much on the information available to them, management of the company may use the findings to know and understand how much information they make available so as to improve on for the best interest of their companies. Lastly, other users like investors and creditors may have knowledge about the level of disclosure by firms which may help them ask questions and demand more from the companies

On the other side of the discussion are the limitations of the study. The study sidelines financial firms that are listed on stock markets which leaves room for consideration for further studies. The determinants used are just a fraction of the set of corporate governance determinants. The limitation makes it misleading to generalize the outcome beyond what it presents. The selected corporate governance attributes for future studies can be widened to cover other equally important determinants that had no appearance in this study. The focus of future study can be directed towards internal corporate governance mechanisms (such as board diversity, managerial ownership, the number of board meetings) and other areas such as economic factors, socio-cultural factors and external corporate governance determinants. Several empirical studies have exposed us to the dynamism of voluntary disclosure but the pursuit of the suggested future study will enhance the holistic understanding of voluntary corporate disclosure in Czech Republic.

\section{Acknowledgements}

This paper was supported by Internal Grant Agency [PEF_DP_2019040] Mendel University in Brno. 


\section{REFERENCES}

AKHTARUDDIN, M., HOSSAIN, M. A. and HOSSAIN, M. 2009. Corporate governance and voluntary disclosure in corporate annual report of Malaysian listed firms. Journal of Applied Management and Accounting Research, 7(1): 1-22.

ALBITAR, K. G. 2015. Corporate governance and voluntary disclosure: Evidence from Jordan. European Academic Research, 2(10): 1-18.

ALFRAIH, M. M. and ALMUTAWA, A. M. 2017. Voluntary disclosure and corporate governance: empirical evidence from Kuwait. International Journal of Law and Management, 59(2): 217-236.

ALLEGRINI, M. and GRECO, G. 2013. Corporate boards, audit committees and voluntary disclosure: evidence from Italian listed companies. Journal of Management and Governance, 17(1): 187-216.

ALVES, H., RODRIGUES, A. M. and CANADAS, N. 2012. Factors influencing the different categories of voluntary disclosure in annual reports: an analysis for Iberian Peninsula listed companies. Review Applied Management Studies Journal, 10(1): 15-26.

AL JANADI, Y., RAHMAN, R. A. and OMAR, N. B. 2013. Corporate governance mechanisms and voluntary disclosure in Saudi Arabia. Research Journal of Finance and Accounting, 4(4): 25-35.

AL MASKATI, M. M. and HAMDAN, A. M. M. 2017. Corporate governance and voluntary disclosure: Evidence from Bahrain. International Journal Economics and Accounting, 8(1): 1-26.

AL-SARTAWI, A. M., ALRAWAHI, F. and SANAD, Z. 2016. Corporate governance and the level of compliance with international accounting standards (IAS-1): Evidence from Bahrain Bourse. International Research Journal of Finance and Economics, 157: 110-122.

AL-SHAMMARI, B. and AL-SULTAN, W. 2010. Corporate governance and voluntary disclosure in Kuwait. International Journal of Disclosure \& Governance, 7: 262-280.

BARAKO, D. G., HANCOCK, P. and IZAN, H. Y. 2006. Factors influencing voluntary disclosure by Kenyan companies. Corporate Governance: An international Review, 14(2): 237-255.

BOKPIN, G. A. and ISSHAQ, Z. 2009. Corporate governance, disclosure and foreign share ownership on the Ghana Stock Exchange. Managerial Auditing Journal, 24: 688-703.

BOESSO, G. and KUMAR, K. 2007. Drivers of corporate voluntary disclosure: A framework and empirical evidence from Italy and the United States. Accounting, Auditing \& Accountability Journal, 20(2): 269-296.

BORROS, C. P., BOUBAKER, S. and HAMROUNI, A. 2013. Corporate governance and voluntary disclosure in France. The Journal of Applied Business Research, 29(2): 561-577.

BOUAZIZ, M. Z. 2014. Corporate governance and voluntary financial disclosure by Canadian listed firms. Management Review: An International Journal, 9: 44-69.

CHAU, G. K. and GRAY, S. J. 2002. Ownership structure and corporate voluntary disclosure in Hong and Singapore. The International Journal of Accounting, 37(2): 247-265.

CHEN, C. J. P. and JAGGI, B. 2000. Association between independent non-executive directors, family control and financial disclosures in Hong Kong. Journal of Accounting and Public Policy, 19: 285-310.

CHENG, E. and COURTENAY, S. 2006. Board composition, regulatory regime and voluntary disclosure. The International Journal of Accounting, 41(3): 262-289.

COOPER, D. R. and SCHINDLER, P. 2008. Business research methods. $10^{\text {th }}$ Edition. Boston: McGraw-Hill Irwin.

CORMIER, D., LEDOUX, M., MAGNAN, M. and AERTS, W. 2010. Corporate governance and information asymmetry between managers and investors. The international Journal of Business in Society, 10(5): 574-589.

ELFEKY, M. I. 2017. The impact of corporate governance on voluntary disclosure in emerging markets: The case of Egypt. Australian Journal of Basic and Applied Sciences, 11(13): 25-41.

ENG, L. and MAK, Y. 2003. Corporate governance and voluntary disclosure. Journal of Accounting and Public Policy, 22(4): 325-345.

FAMA, F. E. and JENSEN, C. M. 1983. Agency problems and residual Claims. The Journal of Law and Economics, 26(2): 327-357.

FORKER, J. J. 1992. Corporate governance and disclosure Quality. Accounting and Business Research, 22(86): 111-125.

FREEMAN, R. E. 1984. Strategic management: A stakeholder approach. Pitman.

GYAMERAH, S. and AGYEI, A. 2016. Voluntary disclosure in financial reporting among listed companies in Ghana: Does corporate governance play a part? Research Journal of Finance and Accounting, 7(24): 110-115.

HANIFFA, R. and COOKE, T. 2002. Culture, corporate governance and disclosure in Malaysian corporations. Abacus, 38(3): 317-349. 
HO, S. S. M. and WONG, K. S. 2001. A study of the relationship between corporate governance structure and the extent of voluntary disclosure. Journal of International Accounting, Auditing and Taxation, 10(2): 139-156.

HTAY, S. N. N. 2012. The impact of corporate governance on the voluntary accounting information disclosure in Malaysian listed banks. Global Review of Accounting and Finance, 3(2): 128-142.

JENSEN, M. C. 1993. The modern industrial revolution, exit and the failure of internal control systems. The Journal of Finance, 8(3): 831-880.

JENSEN, M. C. and MECKLING, W. H. 1976. Theory of the firm: Managerial Behaviour, agency costs and ownership structure. Journal of Financial Economics, 3(4): 305-360.

LIU, Y., VALENTI, A. and CHEN, Y. 2016. Corporate governance and information transparency in Taiwan's public firms: The moderating effect of family ownership. Journal of Management \& Organization, 22: 662-679.

MAK, Y. T. and LI, Y. 2001. Determinants of corporate ownership and board structure: Evidence from Singapore. Journal of Corporate Finance, 7(3): 33-50.

MANSULU, A. and ANARFI, D. 2019. Discretionary disclosure of listed non-financial firms in an emerging market: Evidence from Ghana. Acta Universitatis Agriculturae et Silviculturae Mendelianae Brunensis, 67(3): 823-837.

MEEK, G. K., ROBERT, G. B. and GRAY, S. J. 1995. Factors influencing voluntary annual report disclosure by US, UK and Continental Europe Multinational Corporations. Journal of International Business Studies, 26(3): 555-572.

OECD. 2004. Principles of corporate governance. Paris: OECD publishing service.

OECD. 2014. OECD Corporate governance fact book. OECD.

OFOEGBU, G. N., ODOEMELAM, N. and OKAFOR, R. G. 2018. Corporate board characteristics and environmental disclosure quantity: Evidence from South Africa (integrated reporting) and Nigeria (traditional reporting). Cogent Business and Management, 5(1): 1-27.

OWUSU-ANSAH, S. 1998. The impact of corporate attributes on the extent of mandatory disclosure and reporting by listed companies in Zimbabwe. The International Journal of Accounting, 33(5): 605-631.

PATELLI, L. and PRENCIPE, A. 2007. The relationship between voluntary disclosure and independent directors in the presence of dominant shareholders. European Accounting Review, 16(1): 5-33.

RENTSCH, R. and VAJDIK, L. 2012. Czech Republic. In: Corporate governance: board structure and directors' duties in 34 jurisdictions worldwide. Getting the Deal Through.

ROUF, A. 2011. Corporate characteristics, governance attributes and the extent of voluntary disclosure in Bangladesh. African Journal of Business Management, 5(19): 7836-7845.

SAMAHA, K., DAHAWY, K., HUSSAINEY, K. and STAPLETON, P. 2012. The extent of corporate governance disclosure and its determinants in a developing market: The case of Egypt. Advances in Accounting, 28(1): 168-178.

WALLACE, R. S. O. and NASER, K. 1995. Firm-specific determinants of the comprehensiveness of mandatory disclosure in the corporate annual reports of firms listed on the stock exchanges of Hong Kong. Journal of Accounting, 14(2): 311-368.

WATSON, A., SHRIVES, P. and MARSTON, C. 2002. Voluntary disclosure of accounting ratios in the UK. The British Accounting Review, 34: 289-313.

YERMACK, D. 1996. Higher market valuation of companies with small board of directors. Journal of Financial Economics, 40(2): 185-211.

Contact information

Abdul Mansulu: abdulis4christ@yahoo.com 


\section{APPENDIXES}

Appendix A: Voluntary Disclosure Index Checklist

\begin{tabular}{|c|c|c|}
\hline Voluntary Theme (Sub-indices) & Disclosure Item & Ranges of Scores \\
\hline \multirow{11}{*}{$\begin{array}{l}\text { A. Corporate Governance } \\
\text { Information (CORGOV) }\end{array}$} & 1 Names of Directors & $0-1$ \\
\hline & 2 Educational qualifications (Academic/Professional experience) & $0-1$ \\
\hline & 3 Shareholding in the company & $0-1$ \\
\hline & 4 Directors Remuneration & $0-1$ \\
\hline & 5 Experience of Executive Directors & $0-1$ \\
\hline & 6 Experience of Non-Executive Directors & $0-1$ \\
\hline & 7 Other directorships held by executive directors & $0-1$ \\
\hline & 8 Other directorships held by non-executive directors & $0-1$ \\
\hline & 9 Number of shares owned by management & $0-1$ \\
\hline & 10 Name of principal shareholders & $0-1$ \\
\hline & 11 Number of shares owned by directors & $0-1$ \\
\hline \multirow{20}{*}{$\begin{array}{l}\text { B. Corporate Environment } \\
\text { Information (CORENV) }\end{array}$} & General Information about Economic environment & \\
\hline & 12 General outlook of the economy & $0-1$ \\
\hline & 13 General outlook of the industry & $0-1$ \\
\hline & 14 Specific factors influencing business & $0-1$ \\
\hline & General Corporate Information & \\
\hline & 15 Brief history of the company & $0-1$ \\
\hline & 16 Statement of corporate general objective & $0-1$ \\
\hline & 17 Financial History or Summary of 2 or more years & $0-1$ \\
\hline & 18 Statement of Financial Objectives & $0-1$ \\
\hline & 19 Main products & $0-1$ \\
\hline & 20 Main Markets & $0-1$ \\
\hline & 21 General description of the business & $0-1$ \\
\hline & Specific Corporate Information & \\
\hline & 22 Vision and Mission Statement & $0-1$ \\
\hline & 23 Statement of strategy and Objective & $0-1$ \\
\hline & 24 Impact of strategy on current results & $0-1$ \\
\hline & 25 Impact of strategy on specific results & $0-1$ \\
\hline & 26 Statement of operating goals & $0-1$ \\
\hline & 27 Strategy to improve performance & $0-1$ \\
\hline & 28 Specific statements of strategy and objective & $0-1$ \\
\hline \multirow{9}{*}{ C. Financial Information (FIN) } & 29 Profitability ratio & $0-1$ \\
\hline & 30 Liquidity ratio & $0-1$ \\
\hline & 31 Leverage ratio & $0-1$ \\
\hline & 32 ROCE & $0-1$ \\
\hline & $33 \mathrm{ROE}$ & $0-1$ \\
\hline & 34 Share price at the end of the year & $0-1$ \\
\hline & 35 Earnings per share & $0-1$ \\
\hline & 36 Dividend pay-out policy & $0-1$ \\
\hline & 37 Foreign exchange information & $0-1$ \\
\hline
\end{tabular}




\begin{tabular}{|c|c|c|}
\hline Voluntary Theme (Sub-indices) & Disclosure Item & Ranges of Scores \\
\hline \multirow{7}{*}{ C. Financial Information (FIN) } & 38 Bank loans & $0-1$ \\
\hline & 39 Retained profits & $0-1$ \\
\hline & 40 Advertising & $0-1$ \\
\hline & 41 Cost of goods sold & $0-1$ \\
\hline & 42 Growth rate on earnings & $0-1$ \\
\hline & 43 Intangible assets breakdown & $0-1$ \\
\hline & 44 Other useful ratios & $0-1$ \\
\hline \multirow{5}{*}{$\begin{array}{l}\text { D. Forecasted Information } \\
\text { (FOCST) }\end{array}$} & 45 Projected future profits & $0-1$ \\
\hline & 46 Projected future sales & $0-1$ \\
\hline & 47 Projected cash flows & $0-1$ \\
\hline & 48 Planned capital expenditure & $0-1$ \\
\hline & 49 Forecasted EPS & $0-1$ \\
\hline \multirow{4}{*}{$\begin{array}{l}\text { E. Corporate Social Responsibility } \\
\text { Information (CSR) }\end{array}$} & 50 Charitable donations & $0-1$ \\
\hline & 51 Environmental protection program & $0-1$ \\
\hline & 52 Information on communication service & $0-1$ \\
\hline & 53 Sponsoring public activities & $0-1$ \\
\hline \multirow{8}{*}{$\begin{array}{l}\text { F. Employee Information } \\
\text { (EPLOY) }\end{array}$} & 54 Categories of employees by gender & $0-1$ \\
\hline & 55 Number of trained employees & $0-1$ \\
\hline & 56 Recruitment policy & $0-1$ \\
\hline & 57 Total staff size & $0-1$ \\
\hline & 58 Policy on Training and Development & $0-1$ \\
\hline & 59 Geographical distribution of employees & $0-1$ \\
\hline & 60 Number of local employees to total employees & $0-1$ \\
\hline & 61 Amount spent on training & $0-1$ \\
\hline
\end{tabular}


